\title{
Chapter 3 \\ Research Methods
}

Chapter 1 presented general information on mental health problems among adolescents, both across the world and in Vietnam. That chapter focused on factors known to influence mental health problems and their consequences, and articulated an urgent need to investigate mental health problems among adolescents in Can Tho City, Vietnam. Chapter 2 provided detailed information on the theoretical framework and objectives of this study. This Chapter presents the main research questions, the research approach, setting, design, and methods; it concludes with an exploration of validity and ethical considerations.

\subsection{Research questions}

The main research question for this thesis is:

How can the complex field of mental health problems among adolescents in Vietnam be understood and addressed with sustainable and accessible developments at the school-level?

Corresponding to this main question, and to the research objectives outlined in Chapter 2, four research sub-questions were formulated that informed the studies in this thesis. They are as follows:

1) What are the perspectives of key stakeholders (students, teachers, parents, experts) about the problems and causes of adolescent mental health problems and possible approaches to mitigate them, in Can Tho City, Vietnam?

2) What are the prevalences of different types of mental health problems among Vietnamese secondary school students in Can Tho City, Vietnam?

3) What are the major risk factors associated with mental health problems among these students?

4) How could mental health problems be mitigated to improve quality of life of Vietnamese secondary school students? 
Table 3.1 below presents the research questions and a map of their corresponding chapters in the dissertation.

Table 3.1. Research questions and corresponding dissertation chapters

\begin{tabular}{|c|c|c|c|c|c|}
\hline \multirow[b]{2}{*}{$\begin{array}{l}\text { Research sub- } \\
\text { question }\end{array}$} & \multicolumn{5}{|c|}{ Chapter } \\
\hline & $\begin{array}{c}4 \\
\text { (perspectives) }\end{array}$ & $\begin{array}{c}5 \\
\text { (depression) }\end{array}$ & $\begin{array}{c}6 \\
\text { (self- } \\
\text { esteem) }\end{array}$ & $\begin{array}{c}7 \\
\text { (school } \\
\text { health } \\
\text { officers) }\end{array}$ & $\begin{array}{c}8 \\
\text { (website) }\end{array}$ \\
\hline $\begin{array}{l}\text { 1. What are the } \\
\text { perspectives of key } \\
\text { stakeholders } \\
\text { (students, teachers, } \\
\text { parents, experts) } \\
\text { about the problems } \\
\text { and causes of } \\
\text { adolescent mental } \\
\text { health problems and } \\
\text { possible approaches } \\
\text { to mitigate them, in } \\
\text { Can Tho City, } \\
\text { Vietnam? }\end{array}$ & $\mathrm{X}$ & & & & \\
\hline $\begin{array}{l}\text { 2. What is the } \\
\text { prevalence of } \\
\text { different types of } \\
\text { mental health } \\
\text { problems among } \\
\text { Vietnamese } \\
\text { secondary school } \\
\text { students in Can Tho } \\
\text { City, Vietnam? }\end{array}$ & $\mathrm{X}$ & $\mathrm{X}$ & $\mathrm{X}$ & & \\
\hline $\begin{array}{l}\text { 3. What are the } \\
\text { major risk factors } \\
\text { associated with } \\
\text { mental health } \\
\text { problems among } \\
\text { these students? }\end{array}$ & $\mathrm{X}$ & $\mathrm{X}$ & $\mathrm{X}$ & & \\
\hline $\begin{array}{l}\text { 4. How to mitigate } \\
\text { mental disorders in } \\
\text { order to improve } \\
\text { quality of life of } \\
\text { Vietnamese } \\
\text { students? }\end{array}$ & $\mathrm{X}$ & $\mathrm{X}$ & $\mathrm{X}$ & $\mathrm{X}$ & $\mathrm{X}$ \\
\hline
\end{tabular}




\subsection{Research approach}

To study the complex and ever-changing field of mental health among adolescents in Vietnam, this study employed a transdisciplinary approach and community based participatory research approach.

As part of the transdisciplinary approach, the first step was to meet and discuss with stakeholders from different sectors, with varying expertise and perceptions, including teachers, students, parents, and mental health experts. These groups jointly identified which areas of mental health and which problems were recognized and which should be addressed in the research. We then applied both quantitative and qualitative methods with the engagement of multiple stakeholders, including teachers, parents, students, health officers and mental health experts, in the different stages of research such as exploration, priority setting, planning based on bottom-up needs identification for intervention, and finally in the dissemination of the information gained. The planned approach is described in Figure 3.1 below. 


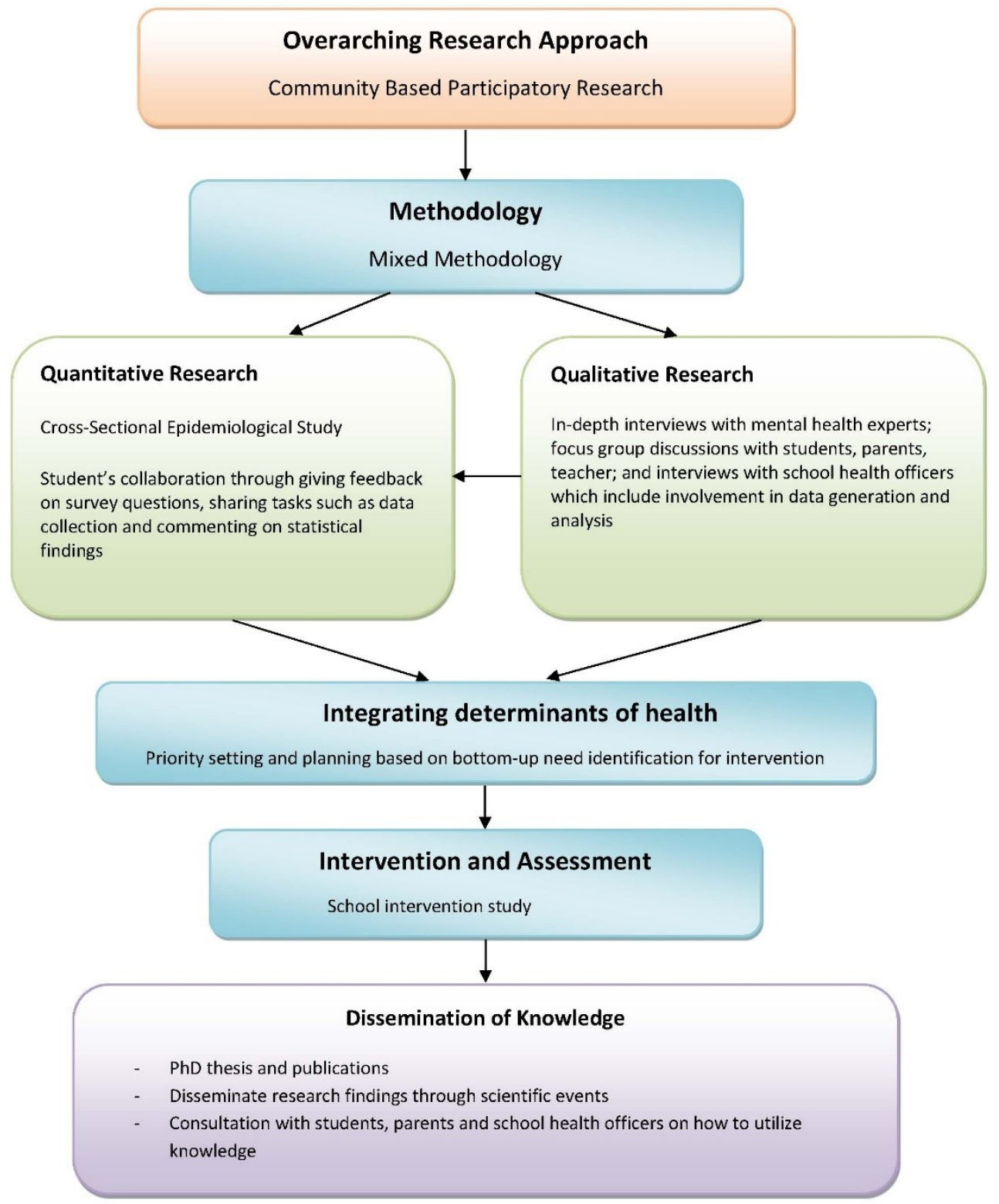

Figure 3.1. Research approach 


\subsection{Research setting, population and selection}

The study took place in Can Tho City (CTC), the capital of Can Tho province. It is the biggest city in the Mekong Delta region of Southern Vietnam, with a population of about 1.273 million (General Statistics Office of Vietnam, 2017b) living in both urban and peri-urban (rural) areas. CTC has over 95,734 lower and upper secondary school students (General Statistics Office of Vietnam, 2017a) attending about 100 schools in nine districts of the city, including both the rural and the urban areas (General Statistics Office of Vietnam, 2017b).

In the first, qualitative phase of the research, a purposive sample of experts from the Vrije Universiteit Amsterdam, Hanoi School of Public Health, Can Tho University of Medicine and Pharmacy, Can Tho Psychiatric Hospital, and other child health professionals, as well as students from commune and district levels, was recruited from March to May 2010. For the qualitative component of Chapter 4, an exploratory qualitative approach included six in-depth interviews conducted with professionals (researchers, psychiatrists, and secondary school teachers); 13 focus group discussions with teachers, parents, and pupils; and 10 individual in-depth interviews with pupils who did not take part in the FGDs. This study was conducted from September to October, 2010, in CTC.

For the quantitative components of Chapters 5 and 6, a cross-sectional study among 1,161 secondary school students was conducted from September to December, 2011. This allowed us to capture the experiences and ideas of a large sample of secondary school students at one time and allowed us to estimate the size of the problem with mental health among the students.

For the qualitative data in Chapter 7, an investigation using semi-structured interviews was conducted among a number of school health officers from November to December, 2015 in CTC.

For the quantitative component of Chapter 8, a cross-sectional study including 643 secondary school students was conducted in November 2016 in the same secondary schools in Can Tho City.

\subsection{Study Design}

To address the question about mental health problems among secondary school students in CTC, the activities can be divided into the phases described below, involving different instruments for data collection. 
1. Exploratory interviews with local experts: This study aimed to explore how stakeholders perceive mental health problems of young people and the related risk factor, to gain insight into their opinions and experiences, and their recommendation on which aspects of mental health problems should be included in the research instruments. Two experts with majors in behavioral science and health education from a university of public health and two psychiatric doctors with knowledge and experience related to adolescent mental health problems and working in a psychiatric clinic participated in these interviews. Depression, anxiety and stress were reported to be the main mental health problems of young people. Game addiction, low concentration in education, attention deficit hyperactivity disorder, low self-esteem, and low self-efficacy were also mentioned. Related risk factors included difficulties in educational performance, familyrelated problems, school violence, academic pressure, and lack of social skills. Regarding the mental health of young people in CTC, depression, anxiety, low self-esteem and low self-efficacy were suggested as the main problems to be explored. For the research instruments, the experts recommended including the following aspects: i) school related items: school connectedness and studying environment, perspective and academic performance, school violence, mental health program at school, studying plan, teachers' caring; ii) family related items: family caring, relationships; and iii) surrounding environment related items: physical activities (sports, leisure activities), soft skills (social integration, coping skills), and Internet use (including exposure to violence on the Internet). It was also noted that some mental health problems are affected by more than one factor so it is important to apply a problem tree to identify the main problem and causes. This information was used to guide the next steps in the collection of data, including identification of mental health problems to be studied and the guidelines for interviews and FGDs.

2. FGDs with students, students' parents and teachers: 13 FGDs (4 with teachers, 4 with parents, and 5 with students), with a purposive sample of 8 to 12 participants each, were conducted in three secondary schools in CTC. Pupils aged between 15 and 18 years old attending grades 10 to 12 were invited by head teachers on a day that pupils had available time. The pupils were selected on the basis of the researcher's request for wide representation with regard to gender and to a range from high to low school performance. Parents were invited by head teachers by letter or by telephone. The focus groups were conducted by two Vietnamese facilitators to take notes and to make 
recordings. The aim was to explore their perceptions about the problems and causes of adolescent mental health problems and possible approaches to mitigate them, in Can Tho City, Vietnam.

3. Exploratory interviews: three individual exploratory interviews with three students from three different schools (as above). The purpose of this activity was to inform researchers about young people's familiarity with the mental health problems, and risk factors for these problems; explore sensitive issues which might not appear in the FGD; obtain opinions and suggestions on the structure and words to use when asking about sensitive problems.

Following this step, the questionnaire for the quantitative research was formulated and piloted on one group of 10 students. After they had completed the questionnaire individually, they were invited to discuss in a group. The purposes of this activity were to obtain feedback from the students on the structure, content and wording of the study instruments to guide revisions, and to identify any suggestions for additions to the questionnaire.

4. Semi-structured interviews: These were carried out with the school health officers, using an interview guideline but allowing divergence from the questions and probing where it seemed to be helpful, to generate the data used for the paper in Chapter 7. These interviews were done after the data on the main issues experienced and reported by the students had been collected and analyzed, so that the school health officers could be asked about those issues in particular.

5. Questionnaires: The first structured questionnaire was formulated based on the research questions, the aims and objectives of the study, the information from the literature, and the results of the investigations described above. The anonymous self-report questionnaires were given to 1260 secondary school students in a classroom setting, to be completed after school without observation, to make the students more comfortable to share information, maximize confidentiality and minimize potential sharing and copying among students, as opposed to filling them in at class in the presence of teachers and researchers. Completed questionnaires were collected and checked for their completion and quality by the researcher. The sampling, stratified for schools and classes, was done according to standard calculations as described in Chapters 5 and 6 . The quantitative data from this step was analyzed using SPSS 18.0, and 
used to answer the questions identified above, as described in Chapters 5 and 6. The second questionnaire was provided to 643 students who had been introduced to the website providing information about mental health. They were asked to complete the questionnaire three weeks after being introduced to the website. The analysis and results are described in Chapter 8 .

Table 3.2. Methods used in each chapter

\begin{tabular}{|l|l|}
\hline \multicolumn{1}{|c|}{ Chapter } & \multicolumn{1}{|c|}{ Methods for data collection } \\
\hline 4: perspectives of pupils, parents, teachers & Exploratory interviews, FGDs \\
\hline 5: occurrence of anxiety, depression, suicidal ideation & Cross-sectional survey \\
\hline 6: low self-esteem related to mental health issues & Cross-sectional survey \\
\hline 7: role of school health officers & Semi-structured interviews \\
\hline 8: role for Internet-based information & Cross-sectional survey \\
\hline
\end{tabular}

\subsection{Validity}

Exploratory interviews with two experts with major in behavior science and health education from a university of public health and two psychiatrists with knowledge and experience related to adolescent mental health problems and working in a psychiatric clinic were conducted to gain insight into which aspects of mental health problems should be included in the qualitative research instruments and design. In addition, the focus group discussion questions and guidelines were revised by a supervisor with more than 30 years' experience of public health research in Vietnam and were pre-tested with first-year students of CTUMP before being applied in the field. Revisions to the guideline were made after the pilot testing to produce the final version applied in the schools.

The key tests used to measure potential issues with mental health were drawn from the international literature. For the quantitative components of Chapters 5 and 6, the Center for Epidemiology Studies Depression test was employed, which has a high internal consistency with Cronbach's alpha coefficients ranging from 0.85 to 0.90 among general population samples (Radloff, 1977). This scale has been validated in Vietnam using confirmatory factor analysis (Nguyen et al., 2007). The Anxiety Scale also showed a high level of internal consistency (Cronbach's alpha ranged from 0.76 to 0.81 ) and has also been validated for use among Vietnamese students (Nguyen et al., 2007). The Educational Stress Scale for Adolescents (ESSA) used to measure educational stress has been also validated to measure the educational stress of adolescents 
in Vietnam, with a high level of internal consistency, Cronbach's alpha of 0.83 (Thai et al., 2012). Our international data collection tools had been translated into Vietnamese and validated in previous studies in Vietnam, so they would be as good as possible to obtain the information we needed (Nguyen et al., 2007).

Using different methods to gain information about the priority questions and key issues, and obtaining that information from a wide range of stakeholders increased the likelihood that the results were an accurate reflection of reality.

\subsection{Ethical considerations}

This study was approved by the Scientific and Training Committee of the Can Tho University of Medicine and Pharmacy. All participants and the parents of student respondents (as well as the students themselves) were informed about the study and given the option of participating. They were all informed that they could withdraw from the study at any time they wished, with no explanation and no consequences. Data were kept confidential; the records from surveys and interviews were numbered, with no names linked to the data. The students completed the questionnaires anonymously.

\section{References}

Adewuya, A. O., \& Famuyiwa, O. O. (2007). Attention deficit hyperactivity disorder among Nigerian primary school children: prevalence and co-morbid conditions. Eur Child Adolesc Psychiatry, 16(1), 10-15. doi: 10.1007/s00787-006-0569-9.

Akin, A., \& Iskender, M. (2011). Internet addiction and depression, anxiety and stress. International Online Journal of Educational Sciences, 3(1), 138-148.

Aldridge, J. M., \& McChesney, K. (2018). The relationships between school climate and adolescent mental health and wellbeing: A systematic literature review. International Journal of Educational Research, 88, 121-145. doi: 10.1016/j.ijer.2018.01.012.

Allen, B. (2008). An analysis of the impact of diverse forms of childhood psychological maltreatment on emotional adjustment in early adulthood. Child Maltreatment, 7(1), 7-28. 
Allison, V. L., Nativio, D. G., Mitchell, A. M., Ren, D., \& Yuhasz, J. (2014). Identifying symptoms of depression and anxiety in students in the school setting. J Sch Nurs, 30(3), 165-172. doi: 10.1177/1059840513500076.

Ambrosini, P. J. (2000). A review of pharmacotherapy of major depression in children and adolescents. Psychiatr Serv, 51(5), 627-633. doi: 10.1176/appi.ps.51.5.627.

Amstadter, A. B., Richardson, L., Meyer, A., Sawyer, G., Kilpatrick, D. G., Tran, T. L., . . . Acierno, R. (2011). Prevalence and correlates of probable adolescent mental health problems reported by parents in Vietnam. Social Psychiatry and Psychiatric Epidemiology, 46, 95-100.

Ang, R. P., \& Huan, V. S. (2006). Relationship between academic stress and suicidal ideation: Testing for depression as a mediator using multiple regression. Child Psychiatry \& Human Development, 37, 133-143.

Arata, C. M., Langhinrichsen-Rohling, J., Bowers, D., \& O'Brien, N. (2007). Differential correlates of multi-type maltreatment among urban youth. Child Abuse \& Neglect, 37, 393-415.

Arenson, M., Hudson, P. J., Lee, N., \& Lai, B. (2019). The Evidence on SchoolBased Health Centers: A Review. Glob Pediatr Health, 6, 2333794X19828745. doi: 10.1177/2333794X19828745.

Aryana, M. (2010). Relationship between self-esteem and academic achievement amongst pre-university students Journal of Applied Science, 10(20), 2474-2477.

Babore, A., Trumello, C., Candelori, C., Paciello, M., \& Cerniglia, L. (2016). Depressive Symptoms, Self-Esteem and Perceived Parent-Child Relationship in Early Adolescence. Front Psychol, 7, 982. doi: 10.3389/fpsyg.2016.00982

Baiden, P., Stewart, S. L., \& Fallon, B. (2017). The role of adverse childhood experiences as determinants of non-suicidal self-injury among children and adolescents referred to community and inpatient mental health settings. Child Abuse Negl, 69, 163-176. doi: 10.1016/j.chiabu.2017.04.011.

Bailey, M. K., Zauszniewski, J. A., Heinzer, M. M., \& Hemstrom-Krainess, A. M. (2007). Patterns of depressive symptoms in children. $J$ Child Adolesc Psychiatr Nurs, 20(2), 86-95. doi: 10.1111/j.1744-6171.2007.00090.x

Balsam, K. F., Lehavot, K., Beadnell, B., \& Circo, E. (2011). Childhood abuse and mental health indicators among ethnically diverse lesbian, gay, and bisexual adults. Journal of Consulting and Clinical Psychology, 78(4), 459-468.

Banerjee, T. D., Middleton, F., \& Faraone, S. V. (2007). Environmental risk factors for attention-deficit hyperactivity disorder. Acta Paediatr, 96(9), 1269-1274. doi: $10.1111 /$ j.1651-2227.2007.00430.x 
Basavaraju, M., \& Navaneetham, J. (2019). Beyond infatuation and love: Review of adolescent mental health manuals in India. Archives of Mental Health, 20(1), 3-8. doi: 10.4103/AMH.AMH_1_19.

Baumeister, R. F., Campbell, J. D., Krueger, J. I., \& Vohs, K. D. (2003). Does high self-esteem cause better performance, interpersonal success, happiness, or health lifestyles? Psychological Science in the Public Interest, 4(1).

Bazargan-Hejazi, S., Alvarez, G., Teklehaimanot, S., Nikakhtar, N., \& Bazargan, M. (1010). Prevalence of depression symptoms among adolescents aged 1217 years in California and the roles of overweight as a risk factor. Ethnicity \& Disease, 20, S1-107-115.

Beran, T., \& Li, Q. (2007). The Relationship between Cyberbullying and School Bullying Journal of Student Wellbeing, 1(2), 15-33.

Berg, P. A. v. d., Mond, J., Eisenberg, M., Ackard, D., \& Neumark-Sztainer, D. (2010). The link between body dissatisfaction and self-esteem in Aaolescents: Similarities across gender, age, weight status, race/ethnicity, and Socioeconomic Status. Journal of Adolescent Health, 47, 290-296.

Bernaras, E., Jaureguizar, J., \& Garaigordobil, M. (2019). Child and Adolescent Depression: A Review of Theories, Evaluation Instruments, Prevention Programs, and Treatments. Front Psychol, 10, 543. doi: 10.3389/ fpsyg.2019.00543.

Birndorf, S., Ryan, S., Auinger, P., \& Aten, M. (2005). High self-esteem among adolescents: longitudinal trends, sex differences, and protective factors. Journal of Adolescent Health, 37(3), 194-201.

Blakemore, S.-J. (2019). Adolescence and mental health. The Lancet, 393(10185), 2030-2031. doi: 10.1016/S0140-6736(19)31013-X.

Blanc, M.-E. (2005). Social construction of male homosexualities in Vietnam. Some keys to understanding discrimination and implications for HIV prevention strategy. UNESCO 2005.

Bloor, M., Frankland, J., Thomas, M., \& Robson, K. (2001). Focus group in social research: SAGE Publication.

Bobak, M., Pikhart, H., Pajak, A. J., Kubinova, R., Malyutina, S., Sebakova, H., . . . Marmot, M. (2006). Depressive symptoms in urban population samples in Russian, Poland and the Czech Republic. The Bristish Journal of Psychiatry, $188,359-365$.

Boden, J. M., Fergusson, D. M., \& Horwood, L. J. (2008). Does adolescent selfesteem predict later life outcomes? A test of the causal role of self-esteem. Dev Psychopathol, 20(1), 319-339. doi: 10.1017/S0954579408000151.

Bohnenkamp, J. H., Stephan, S. H., \& Bobo, N. (2015). Supporting student mental health: the role of the school nurse in coordinated school mental health care. Psychology in the School, 52(7), 714-727. 
Bor, W., Dean, A. J., Najman, J., \& Hayatbakhsh, R. (2014). Are child and adolescent mental health problems increasing in the 21st century? A systematic review. Aust N Z J Psychiatry, 48(7), 606-616. doi: 10.1177/ 0004867414533834.

Bos, A. E. R., Muris, P., Mulkens, S., \& Schaalma, H. P. (2006). Changing selfesteem in children and adolescents: a roadmap for future interventions. Netherlands Journal of psychology, 62, 26-33.

Bottino, S. M., Bottino, C. M., Regina, C. G., Correia, A. V., \& Ribeiro, W. S. (2015). Cyberbullying and adolescent mental health: systematic review. Cad Saude Publica, 31(3), 463-475. doi: 10.1590/0102-311x00036114.

Boydell, K. M., Hodgins, M., Pignatiello, A., Teshima, J., Edwards, H., \& Willis, D. (2014). Using technology to deliver mental health services to children and youth: a scoping review. J Can Acad Child Adolesc Psychiatry, 23(2), 87-99.

Brook, U., \& Boaz, M. (2005). Attention deficit and learning disabilities (ADHD/LD) among high school pupils in Holon (Israel). Patient Educ Couns, 58(2), 164-167. doi: 10.1016/j.pec.2004.07.012.

Butchart, A., Harvey, A. P., Mian, M., \& Furniss, T. (2006). Preventing child maltreatment: a guide to taking action and generating evidence: World Health Organization.

Can Tho City Department of Education and Training. (2016). Annual school year 2015-2016 report on academic performace of students from secondary school in Cantho city: Can Tho City Department of Education and Training.

Canals, J., Voltas, N., Hernandez-Martinez, C., Cosi, S., \& Arija, V. (2019). Prevalence of DSM-5 anxiety disorders, comorbidity, and persistence of symptoms in Spanish early adolescents. Eur Child Adolesc Psychiatry, 28(1), 131-143. doi: 10.1007/s00787-018-1207-z

Cao, F., \& Su, L. (2006). Internet addiction among Chinese adolescents: prevalence and psychological features. Journal Compilation, 33(3), 275-281.

Carvalho, A. F., \& McIntyre, R. S. (Eds.). (2017). Mental Disorders in Primary Care: A Guide to their Evaluation and Management: Oxford University Press.

Center for Behavior Health Statistics and Quality. (2014). The CBHSQ Report. Serious Mental Health Challenges among Older Adolescents and Young Adults. Retrieved 13 December, 2019, from https://www.samhsa.gov/data/ sites/default/files/sr173-mh-challenges-young-adults-2014/sr173-mhchallenges-young-adults-2014/sr173-mh-challenges-young-adults-2014.htm

Central Population and Housing Census Steering Committee. (2010). The 2009 Vietnam Population and Housing Census: Completed results (pp. 5). Hanoi: General Statistics Office of Vietnam. 
Chaiton, M. O., Cohen, J. E., O'Loughlin, J., \& Rehm, J. (2009). A systematic review of longitudinal studies on the association between depression and smoking in adolescents. BMC Public Health, 9(356).

Chaulagain, A., Kunwar, A., Watts, S., Guerrero, A. P. S., \& Skokauskas, N. (2019). Child and adolescent mental health problems in Nepal: a scoping review. Int J Ment Health Syst, 13, 53. doi: 10.1186/s13033-019-0310-y

Chisholm, D. (2006). Dollars, DALYs and decision: economic aspects of mental health system. Geneva: WHO.

Choo, C. C., Harris, K. M., Chew, P. K. H., \& Ho, R. C. (2017). What predicts medical lethality of suicide attempts in Asian youths? Asian J Psychiatr, 29, 136-141. doi: 10.1016/j.ajp.2017.05.008.

Choo, W.-Y., Dunne, M. P., Marret, M. J., Fleming, M., \& Wong, Y.-L. (2009). Multiple-type child maltreatment experiences of adolescents in Malaysia: Prevalence, perpetrators and risk factors. Child Abuse \& Neglect(Submitted for publication).

Cimigo. (2011). Internet Usage and Development in Vietnam. Retrieved 31/10, 2017, from www.cimigo.com/en/download/research_report/348

Clausen, C. E., \& Skokauskas, N. (2018). Child and Adolescent Mental Health: How can we help improve access to care? J. Indian Assoc. Child Adolesc. Ment. Health, 14(1), 10-18.

Cleveland, O. (2008). School-based mental health tool kit for Cuyahoga County school districts: Center for community solutions.

Cohen, P., Cohen, J., Kasen, S., Velez, C. N., Hartmark, C., Johnson, J., . . . Streuning, E. L. (1993). An epidemiological study of disorders in late childhood and adolescence--I. Age- and gender-specific prevalence. $J$ Child Psychol Psychiatry, 34(6), 851-867. doi: 10.1111/j.1469-7610.1993.tb01094.x

Communist Party of Vietnam. (2017). No. 20-NQ/TW: Resolution of the sixth plenary session the 12th Party Central Commitee on the protection, care and improvement of people's health in the new situation. Retrieved March 29th, 2019, from http://unaids.org.vn/wp-content/uploads/2017/12/RESOLUTION.En.pdf

Cooper, S. A., McLean, G., Guthrie, B., McConnachie, A., Mercer, S., Sullivan, F., \& Morrison, J. (2015). Multiple physical and mental health comorbidity in adults with intellectual disabilities: population-based cross-sectional analysis. BMC Fam Pract, 16, 110. doi: 10.1186/s12875-015-0329-3.

Corrigan, P. (2004). How stigma interferes with mental health care. Am Psychol, 59(7), 614-625. doi: 10.1037/0003-066X.59.7.614.

Crocker, J., \& Wolfe, C. T. (2001). Contingencies of Self-Worth. Psychological Review, 108(3), 593-623. 
D'augelli, A. R. (2002). Mental health problems among lesbian, gay, and bisexual youths ages 14 to 21. Clinical Child Psychology and Psychiatry, 7(3), 433-456.

Danielson, M. L., Bitsko, R. H., Ghandour, R. M., Holbrook, J. R., Kogan, M. D., \& Blumberg, S. J. (2018). Prevalence of Parent-Reported ADHD Diagnosis and Associated Treatment Among U.S. Children and Adolescents, 2016. J Clin Child Adolesc Psychol, 47(2), 199-212. doi: 10.1080/15374416.2017. 1417860 .

Das, J. K., Salam, R. A., Lassi, Z. S., Khan, M. N., Mahmood, W., Patel, V., \& Bhutta, Z. A. (2016). Interventions for Adolescent Mental Health: An Overview of Systematic Reviews. J Adolesc Health, 59(4S), S49-S60. doi: 10.1016/j.jadohealth.2016.06.020.

Daviss, W. B. (2008). A review of co-morbid depression in pediatric ADHD: etiologies, phenomology, and treatment. Journal of Child Adolescent Psychophamacology, 18(6), 565-571.

Daya, P., \& Karthikeyan, G. (2018). Depression, anxiety, stress and its correlates among urban school going adolescents in Tamilnadu, India. International Journal of Research in Medical Sciences, 6(8), 2813-2817. doi: 10.18203/2320-6012.ijrms20183275.

Dedovic, K., Wadiwalla, M., Engert, V., \& Pruessner, J. C. (2009). The role of sex and gender socialization in stress reactivity. Dev Psychol, 45(1), 45-55. doi: $10.1037 / \mathrm{a} 0014433$.

Degenhardt, L., Stockings, E., Patton, G., Hall, W. D., \& Lynskey, M. (2016). The increasing global health priority of substance use in young people. Lancet Psychiatry, 3(3), 251-264. doi: 10.1016/S2215-0366(15)00508-8.

Deighton, J., Humphrey, N., Belsky, J., Boehnke, J., Vostanis, P., \& Patalay, P. (2018). Longitudinal pathways between mental health difficulties and academic performance during middle childhood and early adolescence. $\mathrm{Br} \mathrm{J}$ Dev Psychol, 36(1), 110-126. doi: 10.1111/bjdp.12218.

Diep, P. B., Knibbe, R. A., Giang, K. B., \& De Vries, N. (2013). Alcohol-related harm among university students in Hanoi, Vietnam. Glob Health Action, 6, 1-10. doi: 10.3402/gha.v6i0.18857.

Dina, F., \& Pajalic, Z. (2014). How school nurses experience their work with schoolchildren who have mental illness - a qualitative study in a Swedish context. Glob J Health Sci, 6(4), 1-8. doi: 10.5539/gjhs.v6n4p1.

Do, M., Pham, N. N., Wallick, S., \& Nastasi, B. K. (2014). Perceptions of mental illness and related stigma among Vietnamese populations: findings from a mixed method study. J Immigr Minor Health, 16(6), 1294-1298. doi: 10.1007/s10903-014-0018-7. 
Do, Q. D. (2007). Depression and stress among the first year medical students in university of medicine and pharmacy at Ho Chi Minh City, Vietnam. (Master of Public Heath Master of Public Health), Chulalongkorn University, Bangkok.

Do, T. T. H., Correa-Velez, I., \& Dunne, M. P. (2019). Trauma Exposure and Mental Health Problems Among Adults in Central Vietnam: A Randomized Cross-Sectional Survey. Front Psychiatry, 10, 31. doi: 10.3389/ fpsyt.2019.00031.

Do, T. T. T., Le, M. D., Van Nguyen, T., Tran, B. X., Le, H. T., Nguyen, H. D., . . Zhang, M. W. B. (2018). Receptiveness and preferences of health-related smartphone applications among Vietnamese youth and young adults. $B M C$ Public Health, 18(1), 764. doi: 10.1186/s12889-018-5641-0.

Dunne, T., Bishop, L., Avery, S., \& Darcy, S. (2017). A Review of Effective Youth Engagement Strategies for Mental Health and Substance Use Interventions. $J$ Adolesc Health, 60(5), 487-512. doi: 10.1016/j.jadohealth.2016.11.019.

Duplaga, M., \& Dzida, D. (2013). The growth of e-health services focused on mental health. Zdrowie Publiczne i Zarzadzanie, 11(4), 295-301.

Durrant, J. E., \& Ensom, R. (2020). An Eriksonian perspective on physical punishment and Its Impacts on mental health. The Psychoanalytic Study of the Child, 73(1), 30-45. doi: 10.1080/00797308.2020.1690866

El Asam, A., Samara, M., \& Terry, P. (2019). Problematic internet use and mental health among British children and adolescents. Addict Behav, 90, 428-436. doi: 10.1016/j.addbeh.2018.09.007.

Ersan, E. E., Dogan, O., Dogan, S., \& Sumer, H. (2004). The distribution of symptoms of attention-deficit/hyperactivity disorder and oppositional defiant disorder in school age children in Turkey. Eur Child Adolesc Psychiatry, 13(6), 354-361. doi: 10.1007/s00787-004-0410-2.

EU-Vietnam Business Network. (2018). E-commerce industry in Vietnam report. Retrieved 2 December, 2019, from https://evbn.org/e-commerce-industry-invietnam-report-edition-2018/

Evans, C. B. R., Smokowski, P. R., Rose, R. A., Mercado, M. C., \& Marshall, K. J. (2018). Cumulative Bullying Experiences, Adolescent Behavioral and Mental Health, and Academic Achievement: An Integrative Model of Perpetration, Victimization, and Bystander Behavior. J Child Fam Stud, 27. doi: 10.1007/s10826-018-1078-4.

Fazel, M., Hoagwood, U., Stephan, U., \& Ford, T. (2014). Mental health interventions in schools 1: Mental health interventions in schools in highincome countries. The Lancet Psychiatry, 1(5), 377-387. doi: 10.1016/S2215-0366(14)70312-8. 
Fazel, M., Patel, V., Thomas, S., \& Tol, W. (2014). Mental health interventions in schools 2: Mental health interventions in schools in low-income and middleincome countries. Lancet Psychiatry, 1, 388-398. doi: 10.1016/S22150366(14)70312-8.

Finkelhor, D. (2018). Screening for adverse childhood experiences (ACEs): Cautions and suggestions. Child Abuse Negl, 85, 174-179. doi: 10.1016/j.chiabu.2017.07.016.

Fiorilli, C., Grimaldi Capitello, T., Barni, D., Buonomo, I., \& Gentile, S. (2019). Predicting Adolescent Depression: The Interrelated Roles of Self-Esteem and Interpersonal Stressors. Front Psychol, 10, 565. doi: 10.3389/ fpsyg.2019.00565.

Ford, T., Goodman, R., \& Meltzer, H. (2003). The British child and adolescent mental health survey 1999: The prevalence of DSM-IV disorders. Journal of the American Acdemy of Child and Adolescent Psychiatry, 42(10), 1203-1211.

Foster, C. E., Horwitz, A., Thomas, A., Opperman, K., Gipson, P., Burnside, A., . . . King, C. A. (2017). Connectedness to family, school, peers, and community in socially vulnerable adolescents. Child Youth Serv Rev, 81, 321-331. doi: 10.1016/j.childyouth.2017.08.011

Garmy, P., Berg, A., \& Clausson, E. K. (2015). A qualitative study exploring adolescents' experiences with a school-based mental health program. $B M C$ Public Health, 15, 1074. doi: 10.1186/s12889-015-2368-z

Gau, S. S., Chong, M. Y., Chen, T. H., \& Cheng, A. T. (2005). A 3 -year panel study of mental disorders among adolescents in Taiwan. Am J Psychiatry, 162(7), 1344-1350. doi: 10.1176/appi.ajp.162.7.1344

General Statistics Office of Vietnam. (2017a). Statistical yearbook of Veitnam 2017: Education. Retrieved 14 May, 2019, from https://www.gso.gov.vn/ default.aspx?tabid $=512 \&$ idmid $=5 \&$ ItemID $=18940$

General Statistics Office of Vietnam. (2017b). Statistical yearbook of Veitnam 2017: Population and Employment. Retrieved 14 May, 2019, from https://www.gso.gov.vn/default.aspx?tabid=512\&idmid=5\&ItemID=18940

Gewirtz-Meydan, A., \& Finkelhor, D. (2020). Sexual Abuse and Assault in a Large National Sample of Children and Adolescents. Child Maltreat, 25(2), 203214. doi: $10.1177 / 1077559519873975$.

Ghandour, R. M., Sherman, L. J., Vladutiu, C. J., Ali, M. M., Lynch, S. E., Bitsko, R. H., \& Blumberg, S. J. (2019). Prevalence and Treatment of Depression, Anxiety, and Conduct Problems in US Children. J Pediatr, 206, 256-267 e253. doi: 10.1016/j.jpeds.2018.09.021. 
Ghatol, S. D. (2017). Academic Stress among Higher Secondary School Students: A Review. International Journal of Advanced Research in Education \& Technology (IJARET), 4(1), 38-41.

Giang, T. L., \& Duong, K. H. (2007). Social issues under economic transformation and intergration in Vietnam (Vol. 1): Vietnam Development Forum.

Giannakopoulos, G., Tzavara, C., Dimitrakaki, C., Kolaiti, G., Rotsika, V., \& Tountas, Y. (2010). Emotional, behavioural problems and cigarette smoking in adolescence: findings of a Greek cross-sectional study. BMC Public Health, 10(57).

Giannakopoulos, G., Tzavara, C., Dimitrakaki, C., Kolaitis, G., Rotsika, V., \& Tountas, Y. (2010). Emotional, behavioural problems and cigarette smoking in adolescence: findings of a Greek cross-sectional study. BMC Public Health, 10, 57. doi: 10.1186/1471-2458-10-57.

Goldstein, S., \& DeVries, M. (Eds.). (2017). Handbook of DSM-5 Disorders in Children and Adolescents: Springer International Publishing.

Gomez, R., Harvey, J., Quick, C., Scharer, I., \& Harris, G. (1999). DSM-IV $\mathrm{AD} / \mathrm{HD}$ : confirmatory factor models, prevalence, and gender and age differences based on parent and teacher ratings of Australian primary school children. J Child Psychol Psychiatry, 40(2), 265-274.

Goodman, R., Ford, T., Simmons, H., Gatward, R., \& Meltzer, H. (2000). Using the strengths and difficulties questionaire (SDQ) to screen for child psychiatric disorders in a community sample. Bristish Jounal of Psychiatry, 117, 534-539.

Graetz, B. W., Sawyer, M. G., Hazell, P. L., Arney, F., \& Baghurst, P. (2001). Validity of DSM-IVADHD subtypes in a nationally representative sample of Australian children and adolescents. J Am Acad Child Adolesc Psychiatry, 40(12), 1410-1417. doi: 10.1097/00004583-200112000-00011.

Greytak, E., Torres-Guillén, S., Morton, M., Jordan, H., Coyle, S., Mann, A., \& Sun, W.-L. (2019). Cops and No Counselors: How the Lack of School Mental Health Staff Is Harming Students. https://www.aclu.org/ sites/default/files/field_document/030419-acluschooldisciplinereport.pdf.

Haddad, M., Butler, G. S., \& Tylee, A. (2010). School nurses' involvement, attitudes and training needs for mental health work: a UK-wide crosssectional study. $J$ Adv Nurs, 66(11), 2471-2480. doi: 10.1111/j.13652648.2010.05432.x

Harpham, T., \& Tran, T. (2006). From ressearch evidence to policy: mental health care in Vietnam. Bulletin of the World Health Organization, 84(8), 664-668. 
Heinonen, K., Ra“ikko"nen, K., \& Keltikangas-Ja"rvinen, L. (2005). Self-esteem in early and late adolescence predicts dispositional optimism-pessimism in adulthood: A 21-year longitudinal study. Personality and Individual Differences, 39, 511-521.

Heradstveit, O., Skogen, J. C., Hetland, J., Stewart, R., \& Hysing, M. (2019). Psychiatric Diagnoses Differ Considerably in Their Associations With Alcohol/Drug-Related Problems Among Adolescents. A Norwegian Population-Based Survey Linked With National Patient Registry Data. Front Psychol, 10, 1003. doi: 10.3389/fpsyg.2019.01003

Herman, K. C., \& Ostrander, R. (2007). Do family environments and negative cognitions of adolescents with depressive symptoms vary by ethnic group? Journal of Family Psychology, 21(2), 325-330.

Herman, S., Archambeau, O. G., Deliramich, A. N., Kim, B. S. K., Chiu, P. H., \& Frueh, B. C. (2011). Depressive symptoms and mental health treatment in an Ethboracially diverse college student sample. Journal of American College Health, 59(8), 715-720.

Hill, C., Waite, P., \& Creswell, C. (2016). Anxiety disorders in children and adolescents. Paediatrics and Child Health, 26(12), 548553. doi: 10.1016/j.paed.2016.08.007.

Hinh, N. D., \& Minh, H. V. (2013). Public health in Vietnam: scientific evidence for policy changes and interventions. Glob Health Action, 6, 20443. doi: 10.3402/gha.v6i0.20443.

Hoa, D. T., Deb, S., Dunne, M., Baker, P., \& Sun, J. (2016). Analyzing the role of parents in the association between academic stress and depression among Indian adolescents. Vietnam Journal of Preventive Medicine (VJPM), 26(3), 64-70.

Hong Minh. (2008). Mentally ill patients face discrimination. Retrieved 22 June, 2020, from https://vietnamnews.vn/society/health/181201/mentally-illpatients-face-discrimination.html

Huang, Y.-y., \& Chou, C. (2010). An analysis of multiple factors of cyberbullying among junior high school students in Taiwan. Computers in human behavior, 26(6), 1581-1590.

Hughes, K., Bellis, M. A., Hardcastle, K. A., Sethi, D., Butchart, A., Mikton, C., . . . Dunne, M. P. (2017). The effect of multiple adverse childhood experiences on health: a systematic review and meta-analysis. Lancet Public Health, 2(8), e356-e366. doi: 10.1016/S2468-2667(17)30118-4.

Huynh, H. (2010). Cantho: 252 fights among pupils in academic year 2009-2010 (Cần Tho: 252 vụ học sinh đánh nhau trong năm học 2009-2010). Retrieved 18/01, 2011, from http://dantri.com.vn/c25/s25-435026/252-vu-hoc-sinhdanh-nhau-trong-nam-hoc-20092010.htm 
Huynh, Q. N. H. (2009). Exloring the mental health of public health and nursing students in Ho Chi Minh City, Vietnam. (Thesis for Master Degree of Public Health), Queensland University of Technology, Brisbane.

Jadambaa, A., Thomas, H. J., Scott, J. G., Graves, N., Brain, D., \& Pacella, R. (2019). Prevalence of traditional bullying and cyberbullying among children and adolescents in Australia: A systematic review and meta-analysis. Aust $N$ Z J Psychiatry, 53(9), 878-888. doi: 10.1177/0004867419846393.

Jensen, C. M., \& Steinhausen, H. C. (2015). Comorbid mental disorders in children and adolescents with attention-deficit/hyperactivity disorder in a large nationwide study. Atten Defic Hyperact Disord, 7(1), 27-38. doi: 10.1007/s12402-014-0142-1.

Johnson, B. (2017). Paediatric Anxiety Disorders. BMH Medical Journal, 4(3), 91-95.

Johnson, D., Dupuis, G., Piche, J., Clayborne, Z., \& Colman, I. (2018). Adult mental health outcomes of adolescent depression: A systematic review. Depress Anxiety, 35(8), 700-716. doi: 10.1002/da.22777/

Jonsson, J., Maltestam, M., Bengtsson Tops, A., \& Garmy, P. (2017). School Nurses' Experiences Working With Students With Mental Health Problems: A Qualitative Study. J Sch Nurs, 1059840517744019. doi: 10.1177/ 1059840517744019.

Jordan, L. P., Graham, E., \& Vinh, N. D. (2013). Alcohol Use among Very Early Adolescents in Vietnam: What Difference Does Parental Migration Make? Asian Pac Migr J, 22(3), 401-419. doi: 10.1177/011719681302200305.

Kane, M., \& Trochim, W. M. K. (2007). Concept mapping for planning and evaluation (Vol. 50). California: Sage Publications.

Kansky, J., \& Allen, J. P. (2018). Long-Term Risks and Possible Benefits Associated with Late Adolescent Romantic Relationship Quality. $J$ Youth Adolesc, 47(7), 1531-1544. doi: 10.1007/s10964-018-0813-x

Keane, L., \& Loades, M. (2017). Review: Low self-esteem and internalizing disorders in young people - a systematic review. Child and Adolescent Mental Health, 22(1), 4-15. doi: 10.1111/camh.12204.

Keng, S. L., Lee, Y., Drabu, S., Hong, R. Y., Chee, C. Y. I., Ho, C. S. H., \& Ho, R. C. M. (2018). Construct Validity of the McLean screening Instrument for Borderline Personality Disorder in two Singaporean Samples. J Pers Disord, 33(4), 450-569. doi: 10.1521/pedi_2018_32_352.

Kessler, R. C., Andrews, G., Colpe, L. J., Hiripi, E., Mroczek, D. K., Normand, S.L. T., . . Z Zaslavsky, A. M. (2002). Short screening scales to monitor population prevalences and trends in non-specific psychological distress. Psychological Medicine, 32(6), 959-976. 
Kessler, R. C., Barker, P. R., Colpe, L. J., Epstein, J. F., Gfroerer, J. C., Hiripi, E., . . . Zaslavsky, A. M. (2003). Screening for serious mental illness in the general population. Archives of General Psychiatry, 60(2), 184-189.

Kessler, R. C., Crum, R. M., Warner, L. A., Nelson, C. B., Schulenberg, J., \& Anthony, J. C. (1997). Lifetime co-occurrence of DSM-III-R alcohol abuse and dependence with other psychiatric disorders in the National Comorbidity Survey. Arch Gen Psychiatry, 54(4), 313-321. doi: 10.1001/archpsyc. 1997.01830160031005.

Keyes, K. M., Rutherford, C., Popham, F., Martins, S. S., \& Gray, L. (2018). How Healthy Are Survey Respondents Compared with the General Population?: Using Survey-linked Death Records to Compare Mortality Outcomes. Epidemiology, 29(2), 299-307. doi: 10.1097/EDE.0000000000000775.

Kieling, C., Baker-Henningham, H., Belfer, M., Conti, G., Ertem, I., Omigbodun, O., . . . Rahman, A. (2011). Child and adolescent mental health worldwide: evidence for action. Lancet, 378(9801), 1515-1525. doi: 10.1016/S01406736(11)60827-1.

Kim, M.-D., Hong, S.-c., Lee, C.-I., Kwak, Y.-S., Shin, T.-K., Jang, Y.-H., . . . Hwang, S.-E. (2007). Prevalence of depression and correlates of depressive symptoms for residents in the urban part of Jeju Island, Korea. International Journal of Social Psychiatry, 53(2), 123-134.

Kingsbury, M., Sucha, E., Manion, I., Gilman, S. E., \& Colman, I. (2020). Adolescent Mental Health Following Exposure to Positive and Harsh Parenting in Childhood. Can J Psychiatry, 65(6), 392-400. doi: 10.1177/0706743719889551.

Kling, K. C., Hyde, J. S., Showers, C. J., \& Buswell, B. N. (1999). Gender differences in self-esteem: a meta-analysis. Psychology Bulletin, 125(4), 470-500.

Krauss, S., Orth, U., \& Robins, R. W. (2020). Family environment and self-esteem development: A longitudinal study from age 10 to 16. J Pers Soc Psychol, 119(2), 457-478. doi: 10.1037/pspp0000263.

Kuhn, E. S., \& Laird, R. D. (2014). Family support programs and adolescent mental health: review of evidence. Adolesc Health Med Ther, 5, 127-142. doi: 10.2147/AHMT.S48057.

Kumar, K. S., \& Akoijam, B. S. (2017). Depression, Anxiety and Stress Among Higher Secondary School Students of Imphal, Manipur. Indian J Community Med, 42(2), 94-96. doi: 10.4103/ijcm.IJCM_266_15

Kumari, R., \& Gartia, R. (2012). Relationship between Stress and Academic Achievement of Senior Secondary School Students. Asian Journal of Multidimensional Research, 1(3), 153-160. 
Lalonde, J., Turgay, A., \& Hudson, J. I. (1998). Attention-deficit hyperactivity disorder subtypes and comorbid disruptive behaviour disorders in a child and adolescent mental health clinic. Can $J$ Psychiatry, 43(6), 623-628. doi: 10.1177/070674379804300612.

Larsson, M., Bjork, M., Ekebergh, M., \& Sundler, A. J. (2014). Striving to make a positive difference: school nurses' experiences of promoting the health and well-being of adolescent girls. J Sch Nurs, 30(5), 358-365. doi: 10.1177/ 1059840513505223.

Le, H. T., Dunne, M. P., Campbell, M. A., Gatton, M. L., Nguyen, H. T., \& Tran, N. T. (2017). Temporal patterns and predictors of bullying roles among adolescents in Vietnam: a school-based cohort study. Psychol Health Med, 22(sup1), 107-121. doi: 10.1080/13548506.2016.1271953.

Le, H. T. H., Tran, N., Campbell, M. A., Gatton, M. L., Nguyen, H. T., \& Dunne, M. P. (2019). Mental health problems both precede and follow bullying among adolescents and the effects differ by gender: a cross-lagged panel analysis of school-based longitudinal data in Vietnam. Int $J$ Ment Health Syst, 13, 35. doi: 10.1186/s13033-019-0291-x

Le, M. T., Holton, S., Nguyen, H. T., Wolfe, R., \& Fisher, J. (2015). PolyVictimisation among Vietnamese High School Students: Prevalence and Demographic Correlates. PLoS One, 10(5), e0125189. doi: 10.1371/ journal.pone.0125189.

Le, M. T., Holton, S., Nguyen, H. T., Wolfe, R., \& Fisher, J. (2016). Polyvictimisation and health risk behaviours, symptoms of mental health problems and suicidal thoughts and plans among adolescents in Vietnam. Int J Ment Health Syst, 10, 66. doi: 10.1186/s13033-016-0099-x

Le, M. T., Nguyen, H. T., Tran, T. D., \& Fisher, J. R. (2012). Experience of low mood and suicidal behaviors among adolescents in Vietnam: findings from two national population-based surveys. $J$ Adolesc Health, 51(4), 339-348. doi: 10.1016/j.jadohealth.2011.12.027.

Le, M. T. H., Holton, S., Kirkman, M., \& Fisher, J. (2018). "I feel that life is meaningless": Vietnamese adolescents' experiences of and reflections about interpersonal violence. Glob Ment Health (Camb), 5, e12. doi: 10.1017/ gmh.2017.34.

Lebowitz, M. S. (2019). The Implications of Genetic and Other Biological Explanations for Thinking about Mental Disor.ders. The Hastings Center Report, 49(2), S82-S87. doi: 10.1002/hast.1020

Lee, K., Zappelli, R., Goldner, E. M., Vu, N. C., Corbett, K. K., \& Murphy, J. (2015). The Political Economy of Mental Health in Vietnam: Key Lessons for Countries in Transition. Asia and the Pacific Policy Studies, 2(2), 266279. doi: 10.1002/app5.74. 
Li, L., Tuan, N. A., Liang, L. J., Lin, C., Farmer, S. C., \& Flore, M. (2013). Mental health and family relations among people who inject drugs and their family members in Vietnam. Int J Drug Policy, 24(6), 545-549. doi: 10.1016/ j.drugpo.2013.06.007/

Lipps, G. E., Low, G. A., Hallida, S., Morris-Patterson, A., Clarke, N., \& Wilson, R. N. (2010). Research the association of academic track i ng to depressive symptoms among adolescents in three Caribbean countries. Child and Adolescent Psychiatry and Mental Health, 4(16).

Liu, H., \& Shuzhuo, L. (2011). Social Change and Psychological Well-being in Urban and Rural China. Asia Health Policy Program Working Paper Series, 23.

Lu, W. (2019). Adolescent Depression: National Trends, Risk Factors, and Healthcare Disparities. Am J Health Behav, 43(1), 181-194. doi: 10.5993/ AJHB.43.1.15.

Lu, W., \& Xiao, Y. (2019). Adverse childhood experiences and adolescent mental disorders: Protective mechanisms of family functioning, social capital, and civic engagement. Health Behavior Research, 2(1). doi: 10.4148/25721836.1035 .

Lu, Y., Mak, K. K., van Bever, H. P., Ng, T. P., Mak, A., \& Ho, R. C. (2012). Prevalence of anxiety and depressive symptoms in adolescents with asthma: a meta-analysis and meta-regression. Pediatr Allergy Immunol, 23(8), 707715. doi: 10.1111/pai.12000.

Luk, J. W., Gilman, S. E., Haynie, D. L., \& Simons-Morton, B. G. (2018). Sexual Orientation and Depressive Symptoms in Adolescents. Pediatrics, 141(5). doi: 10.1542/peds.2017-3309.

Luu, H. N. (2008). Moving the moutain: renovation medical education in a changing Vietnam. Hanoi, Vietnam: Hanoi Medical University Printing Center.

Machell, K. A., Rallis, B. A., \& Esposito-Smythers, C. (2016). Family environment as a moderator of the association between anxiety and suicidal ideation. J Anxiety Disord, 40, 1-7. doi: 10.1016/j.janxdis.2016.03.002

Mak, K. K., Pang, J. S., Lai, C. M., \& Ho, R. C. (2013). Body esteem in Chinese adolescents: effect of gender, age, and weight. $J$ Health Psychol, 18(1), 4654. doi: $10.1177 / 1359105312437264$.

Manitoba Healthy Schools. (2020). Mental health promotion in schools: Support mental health promotion in Manitoba Schools: Healthy Child Manitoba. https://www.edu.gov.mb.ca/k12/specedu/smh/mh_resource.pdf

Masih, J., \& Rajkumar, R. (2019). Internet Addiction Disorder and Mental Health in Adolescents. Journal of Depression and Anxiety, S13(002). doi: 10.4172/2167-1044.S13-002. 
McClure, A. C., Tanski, S. E., Kingsbury, J., Gerrard, M., \& Sargent, J. D. (2010). Characteristics associated with low self-esteem among US adolescents. Academic Pediatrics, 10, 238-244.

McDowell, I. (Ed.). (2006). Measuring health: A guide to rating scales and questionnaires (3 ed.). New York: Oxford University Press.

McGee, R., \& Williams, S. (2000). Does low self-esteem predict health compromising behaviours among adolescents? Journal of Adolescence, 23, $569-582$.

McKelvey, R., Sang, D., \& Tu, H. (1997). Is there a role for child psychiatry in Vietnam? Australian and New Zealand Journal of Psychiatry, 31(1), 114-119.

McKelvey RS, Davies LC, Sang DL, Pickering KR, \& Tu HC. (1999). Problems and competencies reported by parents of Vietnamese children in Hanoi. $J$ Am Acad Child Adolesc Psychiatry, 38(6), 731-737.

Mental Health Europe. (2001). Mental health promotion of adolescents and young people: Directory of projects in Europe. Retrieved 6th Nov, 2012, from http://www.mhe-sme.org/assets/files/Directory Mental Health Promotion of Adolescents \&Young People.pdf

Mikolajczyk, R. T., Bredehorst, M., Khelaifat, N., Maier, C., \& Maxwell, A. E. (2007). Correlates of depressive symptoms among Latino and Non-Lation White adolescents: Findings from the 2003 California Health Interview Survey. BMC Public Health, 7(21).

Milhausen, R. R., Yarber, W. L., \& Crosby, R. (2003). Self-reported depression ans sexual risk behaviors among a national sample of rural high school students. The Health Education Monograph Series, 20(2), 33-39.

Millings, A., Buck, R., Montgomery, A., Spears, M., \& Stallard, P. (2012). School connectedness, peer attachment, and self-esteem as predictors of adolescent depression. Journal of Adolescence, 35, 1061-1067.

Mina Fazel, V. P., Saji Thomas, Wietse Tol. (2014). Mental health interventions in schools 2: Mental health interventions in schools in low-income and middleincome countries. Lancet Psychiatry, 1, 388-398. doi: 10.1016/S22150366(14)70312-8.

Ministry of Education and Training. (2019). Promote health education for students and school health activities (Đẩy mạnh công tác giáo dục sức khỏe học sinh và hoạt động $\mathrm{y}$ tế học đường). Retrieved 18 August, 2020, from https://moet.gov.vn/Pages/tim-kiem.aspx?ItemID=6197. 
Ministry of Education and Training of Vietnam. (2007). Decision 73/2007/QĐBGDĐT: Decision on promulgating regulations on medical activities in primary schools, junior secondary schools, senior secondary schools and multi-lvel secondary schools (Quyết định ban hành qui định về hoạt động $\mathrm{y}$ tế trong các trường tiểu học, trường trung học cơ sở, trường trung học phổ thông và trường phổ thông có nhiều cấp học). Retrieved August 12, 2017, from https://thuvienphapluat.vn/van-ban/Giao-duc/Quyet-dinh-73-2007-QDBGDDT-Quy-dinh-hoat-dong-y-te-truong-tieu-hoc-trung-hoc-co-so-phothong-60656.aspx

Ministry of Health and Ministry of Education and Training. (2016). Joint Circular No. 13/2016/TTLT-BYT-BGDDT dated May 12, 2016, regulations on healthcare activities in schools. Retrieved March 11, 2019, from https://vanbanphapluat.co/joint-circular-13-2016-ttlt-byt-bgddt-regulationshealthcare-activities-in-schools

Mishna, F., Khoury-Kassabri, M., Gadalla, T., \& Daciuk, J. (2012). Risk factors or involvement in cyber bullying: Victims, bullies and bully-victims. Children and Youth Services Review, 34(1), 63-70. doi: 10.1016/j.childyouth .2011.08.032

Mistry of Health. (2007). Health statistic yearbook. Hanoi: Ministry of Health, Vietnam

Mitchell, J., Vella-Brodrick, D., \& Klein, B. (2010). Positive psychology and the internet: A mental health opportunity. Electronic Journal of Applied Psychology, 6(2), 30-41.

Moen, Ø. L., \& Skundberg-Kletthagen, H. (2018). Public health nurses' experience, involvement and attitude concerning mental health issues in a school setting. Nordic Journal of Nursing Research, 38(2), 61-67. doi: $10.1177 / 2057158517711680$.

Moock, J. (2014). Support from the Internet for individuals with mental disorders: advantages and disadvantages of e-mental health service delivery. Frontiers in Public Health, 2(65), doi: 10.3389/fpubh.2014.0006. doi: 10.3389/ fpubh.2014.0006.

Morrison, W., \& Kirby, P. (2010). Schools as a setting for promoting positive mental health: better practives and perspectives (Literature review): Joint Consortinum for School Health.

Mulrow, C. D., Williams, J. W., Gerety, M. B., Ramirez, G., Montiel, O. M., \& Kerber, C. (1995). Case-finding instruments for depression in primary care settings. Annals of Internal Medicine, 122(12), 913-921.

Murphy, D. A., Shetty, V., Dent, M., Herbeck, D. M., Der-Martirosian, C., Urata, M., \& Yamashita, D.-D. (2010). Adolescent orofacial injury: association with psychological symptoms. Psychology, Health \& Medicine, 15(5), 574-583. 
Murphy, D. A., Shetty, V., Herbeck, D. M., Der-Martirosian, C., Urata, M., \& Yamashita, D. D. (2010). Adolescent orofacial injury: association with psychological symptoms. Psychol Health Med, 15(5), 574-583. doi: 10.1080/13548506.2010.507770.

Murray, L., Dunne, M. P., Van Vo, T., Anh, P. N., Khawaja, N. G., \& Cao, T. N. (2015). Postnatal depressive symptoms amongst women in Central Vietnam: a cross-sectional study investigating prevalence and associations with social, cultural and infant factors. BMC Pregnancy Childbirth, 15, 234. doi: 10.1186/s12884-015-0662-5.

Murray, L. K., Nguyen, A., \& Cohen, J. A. (2014). Child sexual abuse. Child Adolesc Psychiatr Clin $N$ Am, 23(2), 321-337. doi: 10.1016/j.chc. 2014.01.003.

Najman, J. M., Hayatbakhsh, M. R., Clavarino, A., Bor, W., O'Callaghan, M. J., \& Williams, G. M. (2010). Family poverty over the early life course and recurrent adolescent and young adult anxiety and depression: a longitudinal study. Am J Public Health, 100(9), 1719-1723. doi: 10.2105/AJPH.2009. 180943.

Naqvi, S. (2004). Review of child and adolescent psychiatry. The Journal of Lifelong Learning in Psychiatry, 2(4), 529-540.

National High School. (2012). Education in Vietnam. Retrieved 17/12, 2012, from http://www.edcal.com/215425.page

Negriff, S. (2020). ACEs are not equal: Examining the relative impact of household dysfunction versus childhood maltreatment on mental health in adolescence. Soc Sci Med, 245, 112696. doi: 10.1016/j.socscimed.2019.112696

Ng, C. H., Than, P. T., La, C. D., Van Than, Q., \& Van Dieu, C. (2011). The national community mental health care project in Vietnam: a review for future guidance. Australas Psychiatry, 19(2), 143-150. doi: 10.3109/ 10398562.2011.563308.

Nguyen, D. T. (2009). Child Maltreatment and mental health among first year students in Cantho University of Medicine and Pharmacy, Vietnam. (Thesis for Master of Public Health), Queensland University of Technology, Brisbane.

Nguyen, D. T., Dedding, C., Pham, T. T., \& Bunders, J. (2013). Perspectives of pupils, parents, and teachers on mental health problems among Vietnamese secondary school pupils. BMC Public Health, 13(1046). doi: https://doi.org/ 10.1186/1471-2458-13-1046

Nguyen, D. T., Dedding, C., Pham, T. T., Wright, P., \& Bunders, J. (2013). Depression, anxiety, and suicidal ideation among Vietnamese secondary school students and proposed solutions: a cross-sectional study. BMC Public Health, 13(1195). doi: https://doi.org/10.1186/1471-2458-13-1195 
Nguyen, H. B. T., \& Tran, C. V. (2017). Cyberbullying among high school students in Da Nang. Paper presented at the Proceedings of International Conference: The first Southeast Asia Regional conference of Psychology "Human Wellbeing and Sustainable Development".

Nguyen, H. T. (2006). Child maltreatment in Vietnam: Prevalence and associated mental and physical health problems. (Thesis for the Doctor Degree of Philosophy), Queensland University of Techonology, Brisbane.

Nguyen, H. T. L., Nakamura, K., Seino, K., \& Al-Sobaihi, S. (2019). Impact of parent-adolescent bonding on school bullying and mental health in Vietnamese cultural setting: evidence from the global school-based health survey. BMC Psychol, 7(1), 16. doi: 10.1186/s40359-019-0294-z

Nguyen, N. H. P., \& Tran, C. V. (2016). Consequences of cyberbullying among high school students. Paper presented at the Proceedings of International conference: "Psychological trauma and support activities".

Nguyen, T. B. (2011). Industrialization and the changes of Vietnamese families. International Journal of Academic Research in Business and Social Sciences, 1(2), 347-356.

Nguyen, T. H., Dunne, M. P., \& Le, V. A. (2010). Multiple-type child maltreatment and adolescent mental health in Vietnam. Bulletin of the World Health Organization, 88(1), 22-30.

Nguyen, T. H., Le, V. A., \& Dunne, M. (2007). Validity and reliability of depression and anxiety scales using in community-based adolescent research. Vietnam Journal of Public Health, 7(7), 25-31.

Nguyen Thai, Q. C., \& Nguyen, T. H. (2018). Mental health literacy: knowledge of depression among undergraduate students in Hanoi, Vietnam. Int $J$ Ment Health Syst, 12, 19. doi: 10.1186/s13033-018-0195-1.

Nguyen, T. Q., Bandeen-Roche, K., Masyn, K. E., German, D., Nguyen, Y. H., Vu, L. K.-C., \& Knowlton, A. R. (2015). Negative Family Treatment of Sexual Minority Women and Transmen in Vietnam: Latent Classes and Their Predictors. Journal of GLBT Family Studies, 11(3), 205-228. doi: 10.1080/1550428X.2014.964443.

Nguyen, T. V. T. (2010). Clinical presentation of primary school students with Attention deficit and Hyperactivity disorder (In Vietnamese). (Doctoral of Philosophy Doctoral of Philosophy), Vietnam National University, Hanoi.

Nguyen, V. A. T., Nguyen, N. Q. H., Khuat, T. H., Nguyen, P. T. T., Do, T. T., Vu, X. T., . . Vuong, Q. H. (2019). Righting the Misperceptions of Men Having Sex with Men: A Pre-Requisite for Protecting and Understanding Gender Incongruence in Vietnam. J Clin Med, 8(1). doi: 10.3390/jcm8010105 
Nguyen, X. C. (2012). Mental Health a Vietnamese perspective. Retrieved 22 June, 2020, from https://www.vmhs.org.uk/media/17739/mental-health-vietnamese -perspective.pdf

Niemi, M., Thanh, H. T., Tuan, T., \& Falkenberg, T. (2010). Mental health priorities in Vietnam: a mixed-methods analysis. BMC Health Serv Res, 10, 257. doi: 10.1186/1472-6963-10-257.

Nikapota, A. D. (1991). Child psychiatry in developing countries. The British Journal of Psychiatry, 158, 743-751.

Nixon, C. L. (2014). Current perspectives: the impact of cyberbullying on adolescent health. Adolesc Health Med Ther, 5, 143-158. doi: 10.2147/ AHMT.S36456.

OECD Development Centre. (2017). Youth Well-being Policy Review of Viet Nam. Paris: EU-OECD Youth Inclusion Project. http://www.oecd.org/ countries/vietnam/OECDYouthReportVietNam_ebook.pdf.

Olweus, D. (2013). School bullying: development and some important challenges. Annu Rev Clin Psychol, 9, 751-780. doi: 10.1146/annurev-clinpsy-050212185516

Overseas Development Institute and UNICEF. (2018). Mental health and psychosocial wellbeing among children and young people in selected provinces and cities in Viet Nam. Retrieved 8 August, 2020, from https:/www.unicef.org/vietnam/sites/unicef.org.vietnam/files/2018-07/Study on Mental Health-Full Report_ENG.pdf

Overseas Development Institute and UNICEF Vietnam. (2018). Mental health and psychosocial wellbeing among children and young people in selected provinces and cities in Viet Nam. Retrieved $30^{\text {th }}$ December, 2019, from https://www.unicef.org/vietnam/media/976/file/Study on mental health and psychosocial wellbeing of Children and Young people in Viet Nam.pdf

Pan, B., Zhang, L., Zhang, W.-x., \& Lin-qin, J. (2016). The relationship of academic underachievement, academic pressure and effortful control among adolescents: A cross-lagged study. Psychological Development and Education, 6.

Park, Y.-J., Shin, N.-M., Han, K. S., Kang, H. C., Cheon, S.-H., \& Shin, H. (2011). Depression status of academic high school students in Seoul: Mediating role of entrapment. Journal of Korean Academy of Nursing, 41(5), 663-672.

Paschall, M. J., \& Bersamin, M. (2018). School-Based Health Centers, Depression, and Suicide Risk Among Adolescents. Am J Prev Med, 54(1), 44-50. doi: 10.1016/j.amepre.2017.08.022.

Peng, K., Zhu, X., Gillespie, A., Wang, Y., Gao, Y., Xin, Y., . . Chen, R. (2019). Self-reported Rates of Abuse, Neglect, and Bullying Experienced by 
Transgender and Gender-Nonbinary Adolescents in China. JAMA Netw Open, 2(9), e1911058. doi: 10.1001/jamanetworkopen.2019.11058.

Pham, H. D., Nguyen, H. B., \& Tran, D. T. (2015). Prevalence of ADHD in primary school children in Vinh Long, Vietnam. Pediatr Int, 57(5), 856-859. doi: $10.1111 /$ ped.12656.

Pham, T. X. (2011). Study on the situation of sexual abuse in high school students in Nha Trang City (Nghiên cúu tình hình bi lam dụng tình duc ơ hoc sinh phổ thông trung học tại thành phố Nha Trang). (Thesis of Specialization level II), Hue University of Medicine and Pharmacy, Hue.

Pineda, D. A., Lopera, F., Henao, G. C., Palacio, J. D., Castellanos, F. X., \& Grupo de Investigacion, F. (2001). Confirmation of the high prevalence of attention deficit disorder in a Colombian community. Rev Neurol, 32(3), 217-222.

Plana-Ripoll, O., Pedersen, C. B., Holtz, Y., Benros, M. E., Dalsgaard, S., de Jonge, P., . . McGrath, J. J. (2019). Exploring Comorbidity Within Mental Disorders Among a Danish National Population. JAMA Psychiatry, 76(3), 259-270. doi: 10.1001/jamapsychiatry.2018.3658.

Prasad, K. M., Angothu, H., Mathews, M. M., \& Chaturvedi, S. K. (2016). How are social changes in the twenty first century relevant to mental health? Indian J Soc Psychiatry, 32(3), 227-237. doi: 10.4103/0971-9962.193195

Prime Minister of Vietnam. (2006). Directive 23/2006/CT-TTg: Directive on strengthening health care at school (Chỉ thị về việc tăng cường công tác $\mathrm{y}$ tế trong các trường học). Retrieved August 12, 2017, from https://thuvienphapluat.vn/van-ban/Giao-duc/Chi-thi-23-2006-CT-TTg-tangcuong-cong-tac-y-te-truong-hoc-13022.aspx

Prime Minister of Vietnam. (2009). Decision 401/QĐ-TTg: Decision on approving the program on prevention and control of diseases in educational institutions belonging to the public education system (Quyết định về việc phê duyệt chương trình phòng, chống bệnh, tật trong các cơ sở giáo dục thuộc hệ thống giáo dục quốc dân). Retrieved August 12, 2017, from https://thuvienphapluat .vn/van-ban/Giao-duc/Quyet-dinh-401-QD-TTg-phe-duyet-chuong-trinhphong-chong-benh-tat-trong-cac-co-so-giao-duc-thuoc-he-thong-giao-ducquoc-dan-86772.aspx

Pryjmachuk, S., Graham, T., Haddad, M., \& Tylee, A. (2012). School nurses' perspectives on managing mental health problems in children and young people. J Clin Nurs, 21(5-6), 850-859. doi: 10.1111/j.1365-2702.2011 .03838.x

Pullmann, H., \& Allik, J. (2008). Relations of academic and general self-esteem to school achievement. Personality and Individual Differences, 45, 559-564. 
Quek, Y. H., Tam, W. W. S., Zhang, M. W. B., \& Ho, R. C. M. (2017). Exploring the association between childhood and adolescent obesity and depression: a meta-analysis. Obes Rev, 18(7), 742-754. doi: 10.1111/obr.12535

Radloff, L. S. (1977). The CES-D Scale: A self-report depression scale for research in the general population. Applied Psychological Measurement, 1(3), 485-401.

Ravenna, J., \& Cleaver, K. (2016). School Nurses' Experiences of Managing Young People With Mental Health Problems: A Scoping Review. J Sch Nurs, 32(1), 58-70. doi: 10.1177/1059840515620281.

Raws, P. (2019). Messages from Research for Policy and Practice. Child Abuse Review, 28, 240-247. doi: 10.1002/car.2560

Rentala, S., Nayak, R. B., Patil, S. D., Hegde, G. S., \& Aladakatti, R. (2019). Academic stress among Indian adolescent girls. $J$ Educ Health Promot, 8(158). doi: 10.4103/jehp.jehp_116_19.

Rosenberg, M. (1965). Society and the adolescent self-image. Princeton, NJ: Princeton University Press.

Rosenberg, M. (1989). Society and the Adolescent Self-Image (Revised ed.). Middletown, CT: Wesleyan University Press.

Rosenberg, M., Schooler, C., Schoenbach, C., \& Rosenberg, F. (1995). Global selfesteem and specific self-esteem: Different concepts, different outcomes. American Sociological Review, 60(1), 141-156.

Rosvall, P. A., \& Nilsson, S. (2016). Gender-based generalisations in school nurses' appraisals of and interventions addressing students' mental health. BMC Health Serv Res, 16, 451. doi: 10.1186/s12913-016-1710-1.

Rotheram-Borus, M. J. (1994). Suicidal behavior and gay-related stress among gay and bisexual male adolescents. Journal of Adolescent Research, 9(4), 498-508.

Rowland, A. S., Umbach, D. M., Stallone, L., Naftel, A. J., Bohlig, E. M., \& Sandler, D. P. (2002). Prevalence of medication treatment for attention deficit-hyperactivity disorder among elementary school children in Johnston County, North Carolina. Am J Public Health, 92(2), 231-234. doi: 10.2105/ajph.92.2.231.

Rudolph, K. D. (2002). Gender differences in emotional responses to interpersonal stress during adolescence. J Adolesc Health, 30(4 Suppl), 3-13.

Ryan, E. P., \& Redding, R. E. (2004). A review of mood disorders among juvenile offenders. Psychiatric Services, 55(12), 1397-1407. 
Sajjadi, H., Jorjoran Shushtari, Z., Mahboubi, S., Rafiey, H., \& Salimi, Y. (2018). Effect of socio-economic status, family smoking and mental health through social network on the substance use potential in adolescents: a mediation analysis. Public Health, 157, 14-19. doi: 10.1016/j.puhe.2018.01.004.

Sarsons, H., \& Xu, G. (2015). Confidence Men? Gender and Confidence: Evidence among Top Economists. Retrieved 6/03, 2019, from https://scholar.harvard .edu/files/sarsons/files/confidence_final.pdf

Save the Children and Institute of Social and Medical Studies. (2015). Being LGBT Young People in Vietnam: Life on the Streets and the Light through the Crack A Summary of Research Findings. Ho Chi Minh City, Vietnam. https://resourcecentre.savethechildren.net/sites/default/files/documents/lgbt_ young_people_in_vietnam_-_save_the_childrens_report.pdf

Schilling, E. A., Aseltine, R. H., \& Gore, S. (2007). Adverse childhood experiences and mental health in young adults: a longitudinal survey. BMC Public Health, 7(30).

Schomerus, G., \& Angermeyer, M. C. (2008). Stigma and its impact on helpseeking for mental disorders: what do we know? Epidemiol Psichiatr Soc, 17(1), 31-37. doi: 10.1017/s1121189x00002669.

Schraml, K., Perski, A., Grossi, G., \& Simonsson-Sarnecki, M. (2011). Stress symptoms among adolescents: The role of subjective psychosocial conditions, lifestyle, and self-esteem. Journal of Adolescence, 34, 987-996.

Sesar, K., Živčić-Bećirević, I., \& Sesar, D. (2008). Multi-type maltreatment in childhood and psychological adjustment in adolescence: questionnaire study among adolescents in Western Herzegovina Canton. Croatian Medical Journal, 49(2), 243-256.

Sheeber, L., Hops, H., Alpert, A., Davis, B., \& Andrews, J. (1997). Family support and conflict: Prospective relations to adolescent depression. Journal of Abnormal Child Psychology, 25(4), 333-344.

Silva, M. J. D., McKenzie, K., Harpham, T., \& Huttly, S. R. A. (2005). Social capital and mental illness: a systematic review. Journal of Epidemiology \& Community Health, 59, 619-627.

Skundberg-Kletthagen, H., \& Moen, O. L. (2017). Mental health work in school health services and school nurses' involvement and attitudes, in a Norwegian context. J Clin Nurs, 26(23-24), 5044-5051. doi: 10.1111/jocn.14004

Slonje, R., \& Smith, P. K. (2008). Cyberbullying: another main type of bullying? Scand J Psychol, 49(2), 147-154. doi: 10.1111/j.1467-9450.2007.00611.x 
Smith, P., Mahdavi, J., Carvalho, M., \& Tippett, N. (2006). An Investigation Into Cyberbullying, Its Forms, Awareness and Impact, and the Relationship Between Age and Gender in Cyberbullying: A Report to the Anti-Bullying Alliance (pp. https://www.staffsscb.org.uk/Professionals/Key-Safeguarding/ e-Safety/Task-to-Finish-Group/Task-to-Finish-Group-Documentation/

Cyber-Bullying---Final-Report.pdf). University of London: Goldsmiths College.

Sobowale, K., Nguyen, M., Weiss, B., Van, T. T. H., \& Trung, L. T. (2016). Acceptability of internet interventions for youth mental health in Vietnam. Global Mental Health, 3(e22). doi: 10.1017/gmh.2016.18.

Stempel, H., Cox-Martin, M., Bronsert, M., Dickinson, L. M., \& Allison, M. A. (2017). Chronic School Absenteeism and the Role of Adverse Childhood Experiences. Acad Pediatr., 17(8), 837-843. doi: 10.1016/j.acap.2017.09.013

Sun, J., Dunne, M. P., Hou, X.-y., \& Xu, A.-q. (2010). Association between academic stress and mental health among chinese adolescents. (Thesis for the Doctor Degree of Philosophy), Queensland University of Technology, Brisbane.

Tabak, I., \& Zawadzka, D. (2017). The importance of positive parenting in predicting adolescent mental health. Journal of Family Studies, 23(1), 1-18. doi: 10.1080/13229400.2016.1240098.

Thai, T. T. (2010). Educational stress and mental health among secondary and high school students in Ho Chi Minh City, Vietnam. (Master of Public Health Thesis for Master of Public Health), Queensland University of Technology, Brisbane.

Thai, T. T., Cao, P. L. T., Kim, L. X., Tran, D. P., Bui, M. B., \& Bui, H. H. T. (2020). The effect of adverse childhood experiences on depression, psychological distress and suicidal thought in Vietnamese adolescents: Findings from multiple cross-sectional studies. Asian Journal of Psychiatry, 53. doi: 10.1016/j.ajp.2020.102134.

Thai, T. T., Kim, X. L., Nguyen, D. N., Dixon, J., Sun, J., \& Dunne, M. P. (2012). Validation of the Educational Stress Scale for Adolescents (ESSA) in Vietnam. Asia-Pacific Journal of Public Health, XX(X).

Thompson, M. P., Kingree, J. B., \& Lamis, D. (2019). Associations of adverse childhood experiences and suicidal behaviors in adulthood in a U.S. nationally representative sample. Child Care Health Dev, 45(1), 121-128. doi: $10.1111 /$ cch.12617.

Thornicroft, G. (2008). Stigma and discrimination limit access to mental health care. Epidemiol Psichiatr Soc, 17(1), 14-19. doi: 10.1017/s1121189x00002621. 
Tokunaga, R. S. (2010). Following you home from school: A critical review and synthesis of research on cyberbullying victimization. Computers in human behavior, 26(3), 277-287. doi: 10.1016/j.chb.2009.11.014.

Tran, B. X., Huong, L. T., Hinh, N. D., Nguyen, L. H., Le, B. N., Nong, V. M., . . . Ho, R. C. (2017). A study on the influence of internet addiction and online interpersonal influences on health-related quality of life in young Vietnamese. BMC Public Health, 17(1), 138. doi: 10.1186/s12889-0163983-z.

Tran, B. X., Mai, H. T., Nguyen, L. H., Nguyen, C. T., Latkin, C. A., Zhang, M. W. B., \& Ho, R. C. M. (2017). Vietnamese validation of the short version of Internet Addiction Test. Addict Behav Rep, 6, 45-50. doi: 10.1016/ j.abrep.2017.07.001.

Tran, B. X., Zhang, M. W., Le, H. T., Nguyen, H. D., Nguyen, L. H., Nguyen, Q. L. T., ... Ho, R. C. (2018). What Drives Young Vietnamese to Use Mobile Health Innovations? Implications for Health Communication and Behavioral Interventions. JMIR Mhealth Uhealth, 6(11), e194. doi: 10.2196/ mhealth.6490.

Tran, C. V. (2017). Mental Health Care in Vietnam. Taiwanese Journal of Psychiatry (Taipei), 31(4), 287-299.

Tran, C. V., Ngo, D. T., Nguyen, T. T., \& Nguyen, N. H. P. (2015). Students' coping strategies with cyber-victimization. VNU Journal of Sciences: Educational Research, 31(3), 11-24.

Tran, C. V., Nguyen, N. H. P., Weiss, B., Nguyen, L. V., \& Nguyen, D. B. (2018). Definition and Characteristics of "Cyberbullying" among Vietnamese Students. VNU Journal of Science: Education Research, 34(4). doi: 10.25073/2588-1159/vnuer.4212. https://www.researchgate.net/publication /329948112_Definition_and_Characteristics_of_Cyberbullying_among_Viet namese_Students

Tran, D., Shukri1, R., \& Do, D. (2018). Factors Related to Cyber Bullying among High School Students in Hanoi, Vietnam. Canadian Journal of Clinical Nutrition, 6(1), 107-122. doi: 10.14206/canad.j.clin.nutr.2018.01.07.

Tran, P. B. (2007). Improving Knowledge of factors that influence the mental health of school children in Vietnam. (Thesis for the Master of Public Health), Queensland University of Technology, Brisbane.

Tran, Q. A., Dunne, M. P., Vo, T. V., \& Luu, N. H. (2015). Adverse childhood experiences and the health of uUniversity students in eight provinces of Vietnam. Asia Pac $J$ Public Health, 27(8 Suppl), 26S-32S. doi: 10.1177/1010539515589812. 
Tran, T., Fisher, J. R. W., Mello, M. C. d., Rosenthal, D. A., Prior, M. R., LeighWarne, G., \& Nguyen, T. A. (2005). Report of workshop on primary mental health care for mother and children in Vietnam. Hanoi: Research and Training Centre for Community Development (RTCCD).

Tran, T. N. (2008). Vietnamese family in the new international context. http://www.trf.or.th/TRFGallery/Upload/Gallery/.../1000000011.pdf

Triana, R., Keliat, B. A., \& Sulistiowati, N. M. D. (2019). The relationship between self-esteem, family relationships and social support as the protective factors and adolescent mental health. Humanities \& Social Sciences Reviews, 7(1). doi: 10.18510/hssr.2019.715.

Trochim, W. M. K. (1989). An introduction to concept mapping for planning and evaluation. Evaluation and Program Planning, 12(1), 1-16.

Trzesniewski, K. H., Donnellan, M. B., \& Robins, R. W. (2003). Stability of selfesteem across the life span. Journal of Personality and Social Psychology, 84(1), 205-220.

U.S. Centers for Disease Control and Prevention. (2002). Vietnam Media Call Homosexuality "Social Evil," Vow Crackdown. Retrieved 18/01, 2011, from http://www.thebody.com/content/art22986.html

UNICEF. (2016). Summary report on out-of-school children 2016: Viet Nam country study. Retrieved 09 Sep, 2019, from https://www.unicef.org/ vietnam/media/2686/file/Executive summary - Out-of-school-childrenreport-2016.pdf

UNICEF. (2018). The lack of mental health services in remote areas of Viet Nam leaves children and young people in need helpless. Retrieved 2 December, 2019, from https://www.unicef.org/vietnam/press-releases/lack-mental-health -services-remote-areas-viet-nam-leaves-children-and-young-people

UNICEF Viet Nam. (2010). An analysis of the situation of children in Vietnam 2010. Retrieved 21/9, 2018, from https://www.unicef.org/sitan/files/SitAnViet_Nam_2010_Eng.pdf

United Nations Office on Drugs and Crime. (2020). Drug Use prevention. Retrieved 17 May, 2020, from https://www.unodc.org/southeastasiaandpacific/en/whatwe-do/drugs-health-ad/drug-use-prevention.html

van der Ham, L., Wright, P., Van, T. V., Doan, V. D., \& Broerse, J. E. (2011). Perceptions of mental health and help-seeking behavior in an urban community in Vietnam: an explorative study. Community Ment Health J, 47(5), 574-582. doi: 10.1007/s10597-011-9393-x

Veselska, Z., Geckova, A. M., Gajdosova, B., Orosova, O., Dijk, J. P. v., \& Reijneveld, S. A. (2009). Socio-economic differences in self-esteem of adolescents influenced by personality, mental health and social support. European Journal of Public Health, 20(6), 647-652. 
Vuong, A. D., \& Truong, L. V. N. (2009). Community-based haelthcare for children and adolescents: a pilot in 3 dictricts/communes of Vietnam.

Vuong, D. A., Van Ginneken, E., Morris, J., Ha, S. T., \& Busse, R. (2011). Mental health in Vietnam: Burden of disease and availability of services. Asian $J$ Psychiatr, 4(1), 65-70. doi: 10.1016/j.ajp.2011.01.005.

Wade, A., \& Beran, T. N. (2011). Cyberbullying: The New Era of Bullying. Canadian Journal of School Psychology, 26(1), 44-61. doi: 10.1177/ 0829573510396318.

Wang, Y., Tian, L., Guo, L., \& Huebnere, E. S. (2020). Family dysfunction and Adolescents' anxiety and depression: A multiple mediation model. Journal of Applied Developmental Psychology, 66. doi: 10.1016/j.appdev.2019.101090.

Wartberg, L., Kriston, L., Kramer, M., Schwedler, A., Lincoln, T. M., \& Kammerl, R. (2017). Internet gaming disorder in early adolescence: Associations with parental and adolescent mental health. Eur Psychiatry, 43, 14-18. doi: 10.1016/j.eurpsy.2016.12.013

Weber, S., Puskar, K. R., \& Puskar, K. R. (2010). Relationships between depressive symptoms and perceived social support, self-esteem, \& optimism in a sample of rural adolescents. Issues in Mental Health Nursing, 31, 584-588.

Werner-Seidler, A., Perry, Y., Calear, A. L., Newby, J. M., \& Christensen, H. (2017). School-based depression and anxiety prevention programs for young people: A systematic review and meta-analysis. Clin Psychol Rev, 51, 30-47. doi: 10.1016/j.cpr.2016.10.005

WHO-AIMS. (2006). Report on mental health system in Vietnam A report of the assessment of the mental health system in Viet Nam using the World Health Organization - Assessment Instrument for Mental Health Systems (WHOAIMS) (pp. 23). Hanoi, Vietnam.

Wild, L. G., Flisher, A. J., \& Lombard, C. (2004). Suicidal ideation and attempts in adolescents: associations with depression and six domains of self-esteem. Journal of Adolescence, 27, 611-624.

Williams, S. B., O'Conner, E. A., Eder, M., \& Whitlock, E. P. (2009). Screening for child and adolescent depression in Primary care setting: A systematic evidence review for the US preventive service task force. Pediatrics, 123(4), e716-e735.

Winstanley, E. L., Steinwachs, D. M., Stitzer, M. L., \& Fishman, M. J. (2012). Adolescent Substance Abuse and Mental Health: Problem Co-Occurrence and Access to Services. J Child Adolesc Subst Abuse, 21(4), 310-322. doi: 10.1080/1067828X.2012.709453. 
Wolraich, M. L., Wibbelsman, C. J., Brown, T. E., Evans, S. W., Gotlieb, E. M., Knight, J. R., . . . Wilens, T. (2005). Attention-deficit/hyperactivity disorder among adolescents: a review of the diagnosis, treatment, and clinical implications. Pediatrics, 115(6), 1734-1746. doi: 10.1542/peds.2004-1959.

Wood, D., Crapnell, T., Lau, L., Bennett, A., Lotstein, D., Ferris, M., \& Kuo, A. (2018). Emerging Adulthood as a Critical Stage in the Life Course. In N. Halfon, C. B. Forrest, R. M. Lerner \& E. M. Faustman (Eds.), Handbook of Life Course Health Development (pp. 123-143). Cham (CH).

World Bank, SIDA, AUS AID, \& the Royal Netherlands Embassy in cooperation with the Ministry of Health. (2001). Vietnam growing healthy: a review of Vietnam's health sector Hanoi: Vietnam.

World Health Organization. Maternal, newborn, child and adolescent health: Adolescent development. Retrieved 29/07, 2019, from https://www.who.int/ maternal_child_adolescent/topics/adolescence/development/en/

World Health Organization. (2001). The world health report 2001: Mental health, new understand, new hope. Geneva.

World Health Organization. (2004a). Prevention of mental disorders: effective interventions and policy options: summary report. Geneva.

World Health Organization. (2004b). Promoting mental health: Concepts Emerging evidence - Practice. Geneva: World Health Organization. https://www.who.int/mental_health/evidence/en/promoting_mhh.pdf.

World Health Organization. (2005). Mental health policy and service guidance package: Child and adolescent mental health policies and plans. Geneva: WHO.

World Health Organization. (2008). mhGAP Mental Health Gap Action Programme: Scaling up care for mental, neurological, and substance use disorders. https://www.who.int/mental_health/evidence/mhGAP/en/.

World Health Organization. (2012). Depression: A global crisis World Mental Health Day, October 102012.

World Health Organization. (2013). Mental health action plan 2013-2020. https://www.mhinnovation.net/sites/default/files/downloads/resource/MHAP .pdf.

World Health Organization. (2016). Global plan of action to strengthen the role of the health system within a national multisectoral response to address interpersonal violence, in particular against women and girls, and against children. https://apps.who.int/iris/bitstream/handle/10665/252276/9789241511537 -eng.pdf?sequence $=1$.

World Health Organization. (2017). Depression and other common mental disorders: Global health estimates (Vol. WHO/MSD/MER/2017.2). 
World Health Organization. (2018). Adolescent mental health. Retrieved 10th May, 2019, from https:/www.who.int/news-room/fact-sheets/detail/adolescentmental-health

World Health Organization. (2019a). Gender disparities in mental health. Retrieved 18 August, 2019, from https://www.who.int/mental_health/prevention/ genderwomen/en/

World Health Organization. (2019b). Mental disorders. Retrieved 5 Aug, 2020, from https://www.who.int/news-room/fact-sheets/detail/mental-disorders\#. XwixOewG0tA.email

Yaacob, S. N., Juhari, R., Talib, M. A., \& Uba, I. (2009). Loneliness, stress, self esteem and depression among Malaysian adolescents. Jurnal Kemanusiaan Bil, 14. 